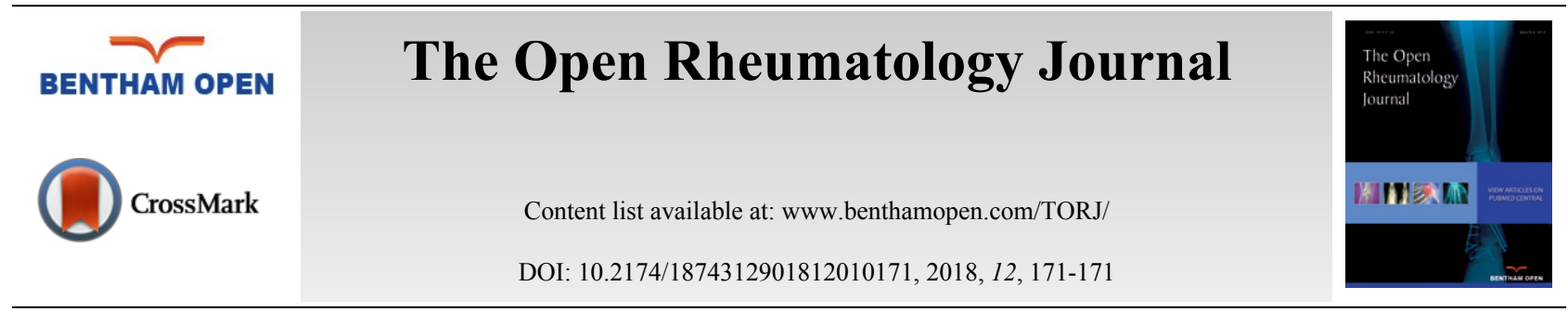

\title{
CORRIGENDUM
}

\section{SLE and Serum Complement: Causative, Concomitant or Coincidental?}

\author{
Vaneet Sandhu ${ }^{1}$ and Michele Quan, ${ }^{2, *}$

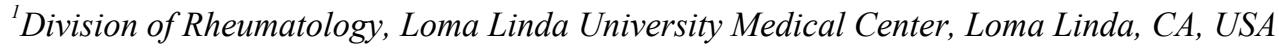 \\ ${ }^{2}$ Department of Internal Medicine, Arrowhead Regional Medical Center, Colton, CA, USA
}

\section{SLE and Serum Complement: Causative, Concomitant or Coincidental?}

The Open Rheumatology Journal, 2017, 11: 113-122

The revised last paragraph of conclusion in abstract is mentioned below:

It is clinically important to find novel ways to assess disease activity in SLE. Increased serum levels of cell-bound complement activation products may more accurately reflect disease activity than conventional serum $\mathrm{C} 3$ and $\mathrm{C} 4$ monitoring.

The original last paragraph of conclusion provided was:

It is clinically important to find novel ways to assess disease activity in SLE. Reduced serum levels of cell-bound complement activation products may more accurately reflect disease activity than conventional serum $\mathrm{C} 3$ and $\mathrm{C} 4$ monitoring.

The revised last paragraph of conclusion is mentioned below:

With recent studies demonstrating that increased levels of serum cell-bound complement activation products may more accurately reflect disease activity than conventional complement $\mathrm{C} 3$ and $\mathrm{C} 4$ monitoring, we believe that this is an important area for future SLE research and look forward to further studies on research in the complement in SLE.

\section{The original last paragraph of conclusion provided was:}

With recent studies demonstrating that reduced levels of serum cell-bound complement activation products may more accurately reflect disease activity than conventional complement $\mathrm{C} 3$ and $\mathrm{C} 4$ monitoring, we believe that this is an important area for future SLE research and look forward to further studies on research in the complement in SLE.

\section{(C) 2018 Sandhu and Quan.}

This is an open access article distributed under the terms of the Creative Commons Attribution 4.0 International Public License (CC-BY 4.0), a copy of which is available at: (https://creativecommons.org/licenses/by/4.0/legalcode). This license permits unrestricted use, distribution, and reproduction in any medium, provided the original author and source are credited. 